\title{
LEGAL DISCOURSE: TEXT ANALYSIS AND TRANSLATION STRATEGIES
}

\author{
OLENA VELYKODSKA, PhD \\ Institute of International Relations \\ Taras Shevchenko National University of Kiev \\ Kiev, Ukraine \\ olena9732@gmail.com
}

\begin{abstract}
The article deals with basic requirements to the translation for specific purposes, namely legal translation. The problem posed here is defining object and theoretical basis of legal translation. The question of the necessity of information search as an integral part of translation strategy has been raised. Detailed analysis revealed that the requirements of professional translators include knowledge of lexical and grammatical peculiarities of both languages in legal sphere; deep understanding of the concepts employed by specialists in particular field and the specialist terms used to express these concepts and their relationships in the source and target languages. It is recommended that evaluation of the translation may be done on the following principles: communicative pragmatic norms of translation; equivalent norms of translation; absence of contextual, cultural, functional, lexico-grammatical mistakes.
\end{abstract}

Key words: legal translation, transformations, adequacy, deviations, terminology 


\title{
ПРАВОВИЙ ДИСКУРС: АНАЛІЗ ТЕКСТУ ТА ЗАСТОСУВАННЯ ПЕРЕКЛАДАЦЬКИХ СТРАТЕГІЙ
}

\begin{abstract}
: У статті розглядаються об'єкт, теоретичні засади та основні вимоги, які висуваються до перекладу текстів для спеціальних цілей, а саме правової та юридичної сфери. Підкреслюється необхідність інформаційно-пошукової діяльності як невід'ємної складової поняття перекладацька стратегія. Визначено, що до професійних вимог до перекладача відносяться знання лексики і граматики обох мов; знання предметної галузі, а саме правової сфери, до якої відноситься текст перекладу і вміння користуватись словниками i iншими джерелами інформації. Слід відзначити, що аналіз зовнішніх і внутрішніх параметрів тексту оригіналу і визначення адекватної перекладацької стратегії на основі доперекладацького аналізу є запорукою вірного перекладацького розуміння тексту. Оцінювання перекладу може базуватись на критеріях пов'язаних з прагматичною нормою перекладу, нормою еквівалентності перекладу i відсутність у перекладі функціонально - змістових, функціонально-нормативних і культурологічних помилок, включаючи їх підвиди.
\end{abstract}

Key words: переклад текстів правової та юридичної сфери, перекладацькі стратегії, адекватність, трансформації

\section{DYSKURS PRAWNY: ANALIZA TEKSTU ISTRATEGIE TRANSLATORSKIE}

\begin{abstract}
Abstrakt: Artykuł koncentruje się na zagadnieniach związanych $\mathrm{z}$ thumaczeniem prawnym, jego podstawami teoretycznymi i wymaganiami, jakie wiążą się $\mathrm{z}$ tego typu thumaczeniem. Autorka zwraca uwagę na konieczność wyszukiwania informacji jako integralnej części strategii thumaczeniowej. Stwierdzona się, że wymagania dotyczące zawodowych tłumaczy obejmują znajomość słownictwa i gramatyki obu języków, dogłębne zrozumienie pojęć używanych przez specjalistów z danej dziedziny oraz znajomość specjalistycznych terminów używanych do wyrażania tych pojęć oraz ich związków w języku źródłowym i docelowym. Zaleca się, aby ocena thumaczenia odbywała się z uwzględnieniem norm związanych z pragmatyką przekładu i ekwiwalencją, a także zwróceniem uwagi na błędy kontekstowe, funkcjonalne i leksykalno-gramatyczne (abstrakt w języku polskim został przygotowany przez redakcję).
\end{abstract}

Słowa klucze: thumaczenie prawne, strategie thumaczeniowe, transformacje, terminologia 
The purpose of translation theory is to reach an understanding of the processes undertaken in the act of translation and, to provide a set of norms for reaching the adequate translation. Translation Studies is a scientific discipline investigating the process of translation, attempting to clarify the question of adequacy and to examine what constitutes meaning within this process. But nowhere is there a theory that pretends to be normative, the goal of the discipline suggests that a comprehensive theory might also be used as a guideline for producing translations, this is a longway from suggesting that the purpose of translation theory is to be proscriptive (Velykodska 2015: 54). Translation Studies which applies to the whole "complex of problems clustered round the phenomenon of translation relations" (Jacobson 1959: 67).

R. Jakobson distinguishes three types of translation:

1. Intralingual translation, or rewording (an interpretation of verbal signs by means of other signs in the same language).

2. Interlingual translation or translation proper (an interpretation of verbal signs by means of some other language).

3. Intersemiotic translation or transmutation (an interpretation of verbal signs by means of signs of nonverbal sign systems).

Having established these three types, R. Jakobson goes on immediately to point to the central problem in all types: that while messages may serve as adequate interpretations of code units or messages, there is ordinarily no full equivalence through translation (Selivanova 2011: 232-239).

It's important to clarify the interconnection between translation equivalents and adequacy. Adequacy of translation means quality of translation. It's worth mentioning the notion of exactness, which has nothing to do with simple copy of the original text by means of target language, even more, text style, exactness; genre are adequate translation features.

Three components are important to define adequacy:

- The most possible exact and full rendering of the original text

- Rendering of the language form of the original text

- Following target language norms 
Equivalent translation is a translation done one of the levels of adequacy. The choice of the translation levels is, actually, a strategy of written translation which is fulfilled while analyzing the text.

We are quite definite about the fact that translational process has 3-structured form:

- comprehension and understanding of the original text; analysis of the source text, situation and background information;

- translation itself; synthesis of the translation model, and

- editing and result analysis of translation; verification of the model against the source and target context (semantic, grammatical, stylistic), situation, and background information resulting in the generation of the final target text (Velykodska 2015: 58).

Each stage highlight special discourse features in order to facilitate understanding of specialized texts. Active reading to fully understand the text, especially those parts which may be difficult from the grammatical, lexical, stylistic or pragmatic point of view, make necessary research. Pre-translation stage includes reading for comprehension, identifying main ideas, target audience, translators problems (difficulties): terminology and grammar peculiarities. Pretranslation analysis of the text: a) documentary research — study of any valuable extra-linguistic information; b) comprehending the writer's intention and main message; c) text organization analysis (logical connectives, cause and effect relations); d) search of translation equivalents; e) focus on the stylistic aspects of the text (genre, register, stylistic devices);1) deciphering and adaptation of units of measure, abbreviations, proper names (Burak 2002: 11-13).

In the translation theory we distinguish two global concepts understanding on the meaning and on the level of sense. Because of these two concepts we consider translation analyses as a main factor of understanding the sense and so as the just right condition to do adequate translation. Translation involves the rendering of a source language (SL) text into the target language (TL) so as to ensure that (1) the surface meaning of the two will be approximately similar and (2) the structures of the SL will be preserved as closely as possible but not so closely that the TL structures will be seriously distorted. The instructor can then hope to measure the students' linguistic competence, by means of the TL product. The stress throughout is on understanding the syntax 
of the language being studied and on using translation as a means of demonstrating that understanding (Bidasyuk 2011: 12-13).

Nevertheless, despite the diversity of methods and approaches, one common feature of much of the research in Translation Studies is an emphasis on cultural aspects of translation, on the contexts within which translation occurs. Once seen as a sub-branch of linguistics, translation today is perceived as an inter-disciplinary field of study and the indissoluble connection between language and way of life has become a focal point of scholarly attention. Of special interest are not only theoretical, methodological, descriptive and applied problems within contrastive linguistics and translation studies in isolation, but also questions concerning their relationships. Every descriptive study of translated texts involves the description translation decisions. The analysing techniques and translation strategies include the syntactic and semantic analysis of the source language sentence with evaluation of the translation difficulties and elimination of those difficulties by means of transformations.

However, in the $21^{\text {st }}$ century, with the rapid development of the text linguistics, communicative linguistics (pragmatics, pragmalinguistics) and discourse analysis, new approaches to viewing functional styles of languages appeared on the agenda. Thus, O.O. Selivanova (Selivanova 2006: 582-583, Selivanova 2011: 695) mentions the traditional approach, according to which the following functional styles of language are distinguished: the official and business style, the publicistic style, the scientific style, the colloquial style, the style of belles-letters. (As we see O.O. Selivanova combines classifications of Galperin and Kozhina into one). Following further ideas O.O. Selivanova and other scholars, we believe that text can be analyzed today on the grounds of the most common features they share - namely on the grounds of the spheres of communication or types of discourse to which certain text belongs. Nowadays it is worthwhile to single out the following types of discourse (spheres of communication): political, legal, scientific, mass media, pedagogical, advertising, religious, everyday, business, fictional, sports and military. It is obvious that this list may be extended further on, moreover within each kind of discourse it is possible to single out "subdiscourses".

We gave several approaches to the notion of discourse. In the most general terms discourse is defined as a complex communicative 
phenomenon, which includes, besides the text itself, other factors of interaction, such as shared knowledge, communicative goals, cognitive systems of participants, their cultural competence, etc. i.e. all that is necessary for successful production and adequate interpretation (comprehension and translation) of the text. We also stressed that for translators it is important to remember is that text is a "macro sign" component of discourse and that discourse is materialized in speech on the basis of the relevant texts.

So the notion of discourse is closely linked to the language in use, to speech interaction or, as Larry Marks writes, to the "totality of codified linguistic usages attached to a given type of social practice (e.g. legal discourse, medical discourse, religious discourse, etc)" (A Little Glossary of Semantics).

We shall come to understand that as an object of linguistic study translation is a complex entity consisting of the following interrelated components: elements and structures of the source texts; elements and structures of the target language; systems of the languages involved in translation; transformation rules to transform the elements and structures of the source texts into those of the target text; conceptual content and organization of the source text; conceptual content and organization of the target text.

Scientists differ in their approaches to the definitions of such notions as "text" and "discourse". Thus, O.O. Selivanova defines "text" as an integral (coherent) semiotic form of lingual, psychological and mental activity of its author (writer or speaker) (Selivanova 2004: 332; Selivanova 2011: 715-718). Text is conceptually and structurally integrated into the objective reality and serves as pragmatic vehicle of communication and is embedded into the semiotic universe of the relevant culture. Michael Hoey writes that firstly the term "text" refers to a piece of continuous language from a single source that is available for linguistic analysis (Hoey 1991: 269).

Similarly there exist many definitions of "discourse", starting with "narrow" and ending up with "broad" ones treating this category in various ways. V.Z. Demyankov describes discourse as a text fragment, which focuses around certain concept. Discourse make up a certain context, which describes relevant participants, objects, conditions, time, etc. the initial structure of discourse may be viewed as a sequence of propositions, connected by logical relations of 
conjunction and disjunction and its basic elements are events, participants of these events and performative information as well as conditions in which events take place, relevant background information, evaluative elements, etc (Demyankov 1982: 7). This approach treats discourse as a specific language (or, more broadly, semiotic) category having relevant texts as macro components of each particular discourse.

According to O.O. Selivanova there are four major approaches to treatment discourse:

1. Coherent text in the contexts of various accompanying factors ontological, social, cultural, psychological, i.e. "text embedded into life";

2. Integral communicative situation (event), which included its participants and text and which is conditioned by various factors, such as social, cultural, ethnic ones, etc.;

3. Sublanguage (style) of speech communication;

4. Pattern of speech communication in a certain social environment that is characterized by specific lingual means. In this respect we may single out legal, administrative, business, scientific, mass media, political, fictional, colloquial, etc. types of discourse (Selivanova 2004: 319; Selivanova 2011: 120-123).

Verbal interaction (communication) either written or oral, always takes place in a certain context or communicative situation. This situation in its turn is embedded into the macro-context of interaction: cultural, social, economic political, historical, etc. In linguistics many scholars express different points of view, but most of them agree that oral and written texts function in a certain discourse. Thus, it is possible to treat discourse as a combination of a text (written or oral) and extralinguistic factors.

Next theoretical point to be given attention to is classification of styles and genres. One of the most general classifications of styles is the following: scientific, official, business, publicistic, belle-letters. Some scholars prefer using the terms of legal discourse, administrative discourse, political discourse, legal discourse etc. depending on their approach while analyzing this or that linguistic problem. Each style can be then divided into sub-styles which in their turn are divided into genres. 
For written translation it is of the main importance which genre this or that text belongs to, communicative tasks awareness, macrostructures and language peculiarities of each particular genre. Text translation needs rendering those genre peculiarities of the original that play the key role in this particular genre.

Any genre has its own structural laws, rules of prohibition and allowance. Such regulations in some genres are strict enough, in others, the whole group of texts, so to say, dictates the specific features. Furthermore, genre theory translation supports the idea of joining the general theory of translation with the problems (approach) of individua 1 style of both the author and the translator. It should also be underlined that we can sometimes encounter incorrect translation of the text because of the ignoring genre and style peculiarities which can be caused either by lack of knowledge of extra linguistics factors or specific knowledge of translation of texts belonging to different genres and styles. To reach the adequate translation of any text it is of vital importance the notion of 'genre and style dominant' (GSD) (Kyiak 2007: 282-284). GSD is the invariant or nucleus of one genre that is presented (realized) in the style of a set of particular texts belonging to this genre. In other words, GSD is the nucleus, the characteristic features that are important for each genre and they create this genre (Bidasyuk 2011: 1-24).

However, whatever the definition may be, what is important for translators to remember is that text is a "macro sign" component of discourse and, on the other hand, discourse is materialized in speech on the basis of the relevant texts. Therefore text is embedded into discourse and both of them function in a communicative situation, which, in its turn, is embedded into the macro-context of interaction: cultural, social, legal, economic, political, historical, religious, etc. The following diagram may graphically represent all the assumptions about levels of linguistic structure that were made above (Holmes 1988: 213).

While teaching students to depict the idea of the original texts it is worth underlining that there are texts belonging to some more regulated genres and this factor presupposes that the depicting of the main idea of such texts must be more regulated as well, while those original texts belonging to more 'flexible' genres could have more variations in the translation that means allowing more freedom for the translation. 
And we completely share the opinion by Burak A.L. who states that to translate scientific and technical texts one has to have high level of translator's informational capacity. Levels of translator's informational capacity are the following:

1. The translator is able to associate a word-sense with a certain very wide class of things.

2. The translator is able to refer the word-sense to particular genus of things or ideas.

3. The translator is able to refer the word-sense to particular species of things or ideas.

4. The translator possesses encyclopedic details of the phenomenon described by the concept in question.

5. The translator possesses a scientific knowledge of the concept in question.

The translator's informational capacity is tightly connected with levels of translation approximations or equivalents. These levels are the following: close approximations (equivalents), adequate approximations (near equivalents), functional-communicative analogues, interpretations or descriptive definitions/translations, loan translations, phonetic transcriptions/transliterations and reproductions of words in their original script (Burak2002: 95- 102). This can be fully applied to the process of translation of legal texts.

To translate legal texts one has to have high level of translator's informational capacity. Levels of translator's informational capacity are the following:

1. The translator is able to associate a word-sense with a certain very wide class of things.

2. The translator is able to refer the word-sense to particular genus of things or ideas.

3. The translator is able to refer the word-sense to particular species of things or ideas.

4. The translator possesses encyclopedic details of the phenomenon described by the concept in question.

5. The translator possesses a scientific knowledge of the concept in question.

The translator's informational capacity is tightly connected with levels of translation approximations or equivalents. These levels 
are the following: close approximations (equivalents), adequate approximations (near equivalents), functional-communicative analogues, interpretations or descriptive definitions/translations, loan translations, phonetic transcriptions/transliterations and reproductions of words in their original script (Burak 2002: 95- 102).

One and the same term may have different meanings in different branches of science. T.R. Kyiak, a well-known researcher of scientific and technical translation, gives recommendations for translating terminology, among them: if the original has some terms not registered in any specialized dictionary and not translated previously, the translator has the responsibility to offer his/her own translation (using reference materials and consulting with experts to define the meaning of it) (Kulezneva and Kolomietz 2012: 282-284).

J.C.Catford's short study tackled the problem of linguistic untranslatability and suggested that in translation, there is substitution of TL meanings for SL meanings: not transference of TL meanings into the SL In transference there is an implantation of SL meanings into the TL text. These two processes must be clearly differentiated in any theory of translation (Catford 1965: 32-37).

One common feature of such of the research in Translation Studies is an emphasis on cultural aspects of translation, on the contexts within which translation occurs. Translation strategies are considered with translation studies emphasis on the main concepts of the translation process and adequacy. Of special interest are not only theoretical, methodological, descriptive and applied problems within contrastive linguistics and translation studies in isolation, but also questions concerning their relationships. Every descriptive study of translated texts involves the description translation decisions. Each translation stage (comprehension and understanding of the original text, translation itself, editing and result analysis of translation) highlight special discourse features in order to facilitate understanding of specialized texts. Pre-translation stage are analysed: reading for comprehension, identifying main ideas, target audience, translators problems (difficulties): terminology and grammar peculiarities. 


\section{Conclusion}

In conclusion we are to emphasize the importance of combining theoretical fundamentals and practices while delivering written translation courses of legal texts may be of the following structure: tasks to speak on the topic of the text; words/terms study which are the stem of the text; key words to understand the parts and whole text; tasks to understand the main idea; tasks to read the text in the following order: word, sentence, paragraph, text; after text tasks include detailed lexical analysis, grammatical difficulties. Evaluation of the translation may be done on the following principles: communicative pragmatic norms of translation; equivalent norms of translation; absence of contextual, cultural, functional, lexical-grammatical mistakes. Detailed analysis revealed that the requirements of professional translators include knowledge of lexical and grammatical peculiarities of both languages in legal sphere; deep understanding of the concepts employed by specialists in particular field and the specialist terms used to express these concepts and their relationships in the source and target languages. It is recommended that evaluation of the translation may be done on the following principles: communicative pragmatic norms of translation; equivalent norms of translation; absence of contextual, cultural, functional, lexico-grammatical mistakes. A frequency analysis legal terminology was conducted for identifying their patterns of use during translation depending on stylistic and genre features of texts and simultaneously correlation of the interpretation of legal terms.

\section{Bibliography}

A Little Glossary of Semantics. Translated by Larry Marks. Revuetectonic.net.

Bidasyuk, Natalya. 2011. Translation course. English - Ukrainian. Kiyv: Znannya.

Burak, Alexander. 2002. Translating Culture: Perevod i mezhkulturnaya komunikatsiya. Etap. 1: Uroven' slova 
(Translating Culture: Translation and cross-cultural communication. Stage 1: Words Level). Moscow: R.Valent.

Catford, John. 1965. A Linguistic Theory of Translation. London: Oxford University Press.

Demyankov, Volodymyr. 1982 Anglo-russkie terminy po prikladnoy lingvistike i avtomaticheskoy pererabotke teksta (EnglishRussian terms in applied linguistics and automatic texts processing), Metody analiza teksta: 288.

Hoey, Michael. 1991. Patterns of Lexis in Text. Oxford: Oxford University Press.

Holmes, John. 1988. Translated! Literary Translation and Translation Studies. Amsterdam: Rodofi.

Jakobson, Roman. 1959. On Linguistic Aspects of Translation. In On Translation R.A. Brower (ed.). Cambridge: Harvard University Press.

Kulezneva Svitlana and Kolomietz Svitlana. Zhanrovo-stul'ova dominanta $\mathrm{v}$ perekladi tekstiv internet-resursu (genre and style dominant in translation texts from Internet). Funktsionalnaya lingvistika 3:282-284.

Kyiak, Taras. 2007. Functions and translation of terms in specialized texts . Bulletin Zhytomyr State University named after Ivan Franko 32: 104-108.

Selivanova, Olena. 2004. Osnovu lingvisticheskoj teorii teksta $i$ kommunikatsii. Linguistic theory of text and communication basis. Kyiv: Vovchok.

Selivanova, Olena. 2011. Suchasna lingvistuka: terminologichna entsuklopediy. Modern linguistics: terminological encyclopedia), Poltava: Dovkillya-K.

Velykodska Helena. 2015. The Application of Translation Strategies in Written Translation Teaching Process. Visnyk National Technical University of Ukraine Kiev Polytechnical Institute 5: 54-64. 